\title{
Gibberellic acid promotes dormancy-breaking of rice seeds and the formation of abnormal seedlings
}

\author{
O ácido giberélico promove a superação da dormência de sementes de arroz e a formação de \\ plântulas anormais
}

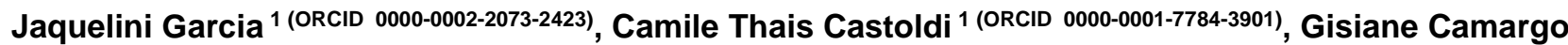 de Andrade 1 (ORCID 0000-0003-2873-8480), Cileide Maria Medeiros Coelho ${ }^{1 *}$ (ORCID 0000-0001-9528-7371), Virgílio Gavicho Uarrotta 2 (ORCID 0000-0002-2974-1625)

1Universidade do Estado de Santa Catarina, Lages, Santa Catarina, Brasil. * Author for correspondence: cileide.souza@udesc.br
${ }^{2}$ Pontificia Universidad Católica de Valparaíso, Quillota, Valparaíso, Chile.

Submission: 17/12/2020 / Acceptance: 18/08/2021

\begin{abstract}
Rice is one species that present dormancy after harvest and can be prolonged during seed storage. This work aimed to determine whether gibberellic acid (GA3) is an efficient promoter of dormancy-breaking in rice seeds and evaluate changes in biological structures via histochemistry. The cultivar used was SCS122 Miura submitted to $0 \mathrm{mg} \mathrm{L}-1,500 \mathrm{mg} \mathrm{L}-1$, and $1000 \mathrm{mg} \mathrm{L}-1$ of GA3. Germination, viability, root, shoot and seedling length, starch optical microscopy, and quantification of total soluble sugars were performed. The use of $500 \mathrm{mg} \mathrm{L}-1$ and $1000 \mathrm{mg} \mathrm{L}-1$ of GA3 was efficient in dormancy-breaking rice seeds, reducing the percentage of dormant seeds to $4 \%$ and $1 \%$, respectively. Despite lowering the dormancy percentage, the presence of GA3 causes an increase in the percentage of abnormal seedlings. Therefore, it cannot be recommended as a method of dormancy-breaking rice seeds at the concentrations used. Optical microscopy is efficient to verify that with the dormancy-breaking, the degradation of starch granules occurs, increasing the availability of total soluble sugars for the growth and development of seedlings.
\end{abstract}

KEYWORDS: biochemistry, $\mathrm{GA}_{3}$, histochemistry, starch, total soluble sugars.

\section{RESUMO}

O arroz é uma das espécies que apresenta dormência após a colheita, podendo esta ser prolongada durante $o$ armazenamento das sementes. Este trabalho teve por objetivo determinar se $o$ ácido giberélico $\left(\mathrm{GA}_{3}\right)$ é um promotor eficiente da superação de dormência em sementes de arroz e avaliar mudanças nas estruturas biológicas via histoquímica. A cultivar utilizada foi a SCS122 Miura submetida a $0 \mathrm{mg} \mathrm{L}^{-1}, 500$ $\mathrm{mg} \mathrm{L}^{-1}$ e $1000 \mathrm{mg} \mathrm{L}^{-1}$ de $\mathrm{GA}_{3}$. Foram realizadas análises de germinação, viabilidade, comprimento de raiz, parte aérea e plântula, microscopia óptica do amido e quantificação dos açúcares solúveis totais. A utilização de $500 \mathrm{mg} \mathrm{L}^{-1}$ e $1000 \mathrm{mg} \mathrm{L}^{-1}$ de GA $\mathrm{G}_{3}$ foi eficiente para a superação da dormência de sementes de arroz, reduzindo o percentual de sementes dormentes para $4 \%$ e $1 \%$ respectivamente. Apesar de reduzir o percentual dormência, a presença de $\mathrm{GA}_{3}$ provoca aumento do percentual de plântulas anormais, e por isso, nas concentrações utilizadas, não pode ser recomendado como método de superação em sementes de arroz. A microscopia óptica é eficiente para verificar que com a superação de dormência, ocorre a degradação dos grânulos de amido, aumentando a disponibilidade de açúcares solúveis totais para o crescimento e desenvolvimento de plântulas.

PALAVRAS-CHAVE: bioquímica, $\mathrm{GA}_{3}$, histoquímica, amido, açúcares solúveis totais.

\section{INTRODUCTION}

Dormancy has been defined as a temporary absence of germination under favorable environmental conditions (BEWLEY et al. 2013), probably caused by mechanisms located in the seeds (MARCOS FILHO 2015). It is an important strategy for seed survival, which allows plants to disperse germination over time and to avoid that occurs in adverse conditions, reducing the risk of failure, and promoting the perpetuation of the species (LONG et al. 2015).

Rice is one species that presents dormancy after harvest and can be prolonged during the seed storage. When not overcome during storage, it can cause serious problems in emergence that can 
compromise productivity.

Seed germination can be defined as "the beginning of the life history for seed plants" (ZHAO et al. 2018). It has been suggested that one way in which the environment indirectly affects seed germination is through the types and amounts of compounds transferred from the mother plant to the seeds. This transfer of compounds to seeds includes carbohydrates, proteins and lipids, which are the major reserves in most seeds. The definition of germination sensu stricto is the complex process from water uptake of dry seeds (imbibition) to radicle protrusion through the seed coat (ZHAO et al. 2018).

In rice seeds, dormancy may result from the hormonal balance between promoters and growth regulators that have a fundamental role in the seed germination process (SHU et al. 2016). Abscisic acid (ABA) has an important role by suppressing cellular activities related to germination, while the gibberellins (GA) have an opposite effect (NÉE et al. 2017). Therefore, the balance between ABA-GA is a decisive factor for dormancy-breaking or not (BEWLEY et al. 2013).

Recommended methods for evaluation of dormancy-breaking (i.e., pre-drying, immersion in sodium hypochlorite solution, pre-heating) are time consuming, lasting 16 to 96 hours of analysis (BRASIL 2009). The longer time needed and lack in efficiency of those reported methods limit the evaluation of the physiological quality of the seeds immediately after the harvest, making it difficult to decide whether or not to approve the seed lots to be marketed (BALDI et al. 2012).

In addition to being widely used for dormancy-breaking of several species that present physiological dormancy (YAO \& SHEN 2018), gibberellic acid has also been indicated by the seed analysis rules (BRASIL 2009) as a specific method for dormancy-breaking of many genus of Poaceae family (i.e., Avena sativa, Hordeum vulgare, Secale cereale and Triticum aestivum). Despite the reported studies, evidences in the literature regarding its effect as dormancy-breaking promoter in rice are not conclusive and it is important to elucidate the culture's response to $\mathrm{GA}_{3}$ (GAO \& CHU 2020). This research hypothesized that gibberellic acid also acts as dormancy-breaking promoter in rice cultivars.

Gibberellic acid induces the biosynthesis of the amylase that acts in the starch hydrolysis, converting it into soluble sugars (BEWLEY et al. 2013). While the dormancy is overcome, the mobilization of reserves increases into the growing points (VIEIRA et al. 2010).

With the activation of specific enzymes for starch degradation, an increase in the availability of total soluble sugars needed for embryo development is observed giving rise to seedlings (ALI \& ELOZEIRI 2017). VIEIRA et al. (2002) verified that gibberellic acid is efficient for dormancy-breaking in rice seeds and that the activity of the $\alpha$-amylase enzyme may be an indicator of the degree of the dormancy.

Histochemistry or "chemistry in the context of biological tissue" is an invaluable set of techniques used to visualize biological structures. This field lies at the interface of organic chemistry, biochemistry, and biology. It is an important technique that is used for the visualization of biological structures. As such, it is concerned with the identification and distribution of various chemical components of tissues through the use of stains, indicators as well as microscopy. The field uses disparate techniques to accomplish the specific labeling of biological structures (LAVIS 2011).

Histochemical techniques are powerful tools in biological systems and have been largely reported in the literature to study seed reserve mobilization during germination in passiflora (TOZZI \& TAKAKI 2011, ALENCAR et al. 2012). It can be used to correlate germination after dormancy-breaking and seed reserves as well as their mobilization. Besides allowing to study early seedling establishment (ALENCAR et al. 2012) and to monitor changes in starch, proteins, and fatty acids (UARROTA et al. 2011). In this regard, histochemical analyses were used in this study to monitor changes in starch degradation and mobilization of reserves from endosperm to growing points of seed embryo.

Thus, the main goals of this work were to determine if the gibberellic acid is an efficient dormancybreaking promoter in rice and the possibility of the use of histochemical analysis in this kind of evaluation.

\section{MATERIAL AND METHODS}

\section{Physiological parameters: Sample preparation, gibberellic acid solutions and experimental design}

Rice dormant seed samples of cultivar SCS122 Miura (2017/2018 harvest) were used for the experiment following a completely randomized design (CRD) with four repetitions $(n=4)$ (BRASIL 2009). The working sample consisted of $70 \mathrm{~g}$ of the previously homogenized and reduced average sample $(1 \mathrm{~kg})$. From the "working sample" $(70 \mathrm{~g})$, four "sub-samples" of $17.5 \mathrm{~g}$ were obtained using a sample splitter and these were used for subsequent physiological, biochemical, and histochemical analyses (BRASIL 2009; COELHO et al. 2010). The sample humidity was determined using an oven ( $105^{\circ} \mathrm{C}$ for 24 hours) (BRASIL 2009). $500 \mathrm{mg} \mathrm{L}^{-1}$ gibberellic acid solution was prepared by dissolving $500 \mathrm{mg}$ of $\mathrm{GA}_{3}$ in $1 \mathrm{~L}$ of water and 
$1000 \mathrm{mg} \mathrm{L}^{-1}$ of $\mathrm{GA}_{3}$, by dissolving $\mathrm{GA}_{3}$ in $1 \mathrm{~L}$ sodium phosphate buffer $(0.01 \mathrm{M}, \mathrm{pH} 7)$ according to the seed analysis rules (BRASIL 2009). The physiological and agronomic parameters evaluated were the germination rate, normal and abnormal seedlings, non-germinated seeds, seed viability by tetrazolium test, root, shoot and seedling length.

\section{Seed germination rate}

Four repetitions of 100 seeds per treatment were used. First, seeds were placed in "germitest" germination paper previously moistened (three times equivalent of paper mass) with deionized water, 500 $\mathrm{mg} \mathrm{L}^{-1} \mathrm{GA}_{3}$ solution and $1000 \mathrm{mg} \mathrm{L}^{-1}$ of $\mathrm{GA}_{3}$ solution, respectively, according to the seed analysis rules (BRASIL 2009). The paper rolls were then packed in plastic bags and then stored in Germinator (Mangelsdorf) in a vertical position and maintained under $25 \pm 2 \stackrel{\circ}{\circ}$ for 14 days. Evaluations were made at 7 and 14 days after, and results were expressed as a percentage (\%).

\section{Seed viability by tetrazolium test}

Seeds without radicle protrusion in each treatment in the previously reported test were subject to the tetrazolium test with the main aim of determining their viability. Seeds were sliced longitudinally through the embryo and $3 / 4$ of endosperm and then immersed in a solution of 2,3,5 triphenyl tetrazolium chloride $(0,1 \%)$ during three hours at $35 \stackrel{\circ}{\circ}$ in dark ambient, according to the methodology described in the seed analysis rules (BRASIL 2009). The number of inviable seeds and dormant (viables) was determined, and the results were expressed in percentage (\%).

\section{Root, shoot and seedling length}

Ten normal seedlings were randomly selected in each treatment and each repetition. Then root, shoot, and seedling lengths were measured. The average length of the roots, shoots and the seedlings were determined as described by NAKAGAWA (1999). Results were expressed in mm per seedling.

\section{Biochemical parameters evaluated by UV-visible spectroscopy and histochemistry: Seed Sampling}

The germination test was set up, as described above. The paper rolls were then packed in plastic bags and stored in a Germinator (Mangelsdorf) in a vertical position and maintained under $25 \pm 2{ }^{\circ} \mathrm{C}$ until $50 \%$ appearance of primary root protrusion with at least $2 \mathrm{~mm}$ length. Such pre-requisite was attained 46 hours after starting the test. Then, palea and seed bark were manually removed (COX et al. 2010) and the remaining part were dried by liquid nitrogen and stored under - $20{ }^{\circ} \mathrm{C}$ (ANDRADE et al. 2020) until the analysis of total soluble sugars and histochemistry analysis.

\section{Total soluble sugars (TSS)}

TSS was determined according to the methodology by CLEGG (1956) with small modifications. The extract was obtained from $250 \mathrm{mg}$ of the sample, which was grinded and mixed with $25 \mathrm{~mL}$ of ethanol $80 \%$, during $15 \mathrm{~min}$ in water bath ( $60^{\circ} \mathrm{C}$ ), centrifuged (7 min, $3000 \mathrm{rpm}$, Model Centrifuge $5810 \mathrm{R}$, Eppendorf) and the supernatant was collected. To the residual part, $30 \mathrm{~mL}$ of ethanol $80 \%$ was added, mixed and centrifuged again. The two supernatants were binded and used as extract for TSS assay. Anthrone solutions were prepared by mixing $0.04 \mathrm{~g}$ of anthrone with $1 \mathrm{~mL}$ of water and $20 \mathrm{~mL}$ of sulfuric acid. All analysis were made using four repetitions. The assay of TSS was performed by mixing $300 \mu \mathrm{L}$ of extract, $700 \mu \mathrm{L}$ of water and 2 $\mathrm{mL}$ of the anthrone solution in test tubes. The tubes were placed in water bath $(3 \mathrm{~min}, 96 \stackrel{\circ}{\circ} \mathrm{C})$ and then followed by absorbance read at $620 \mathrm{~nm}$ using an UV-visible spectrophotometer (UV-VIS SPECTRO 800D, Marte Científica) and results expressed as means \pm standard deviation in $\mathrm{mg} \mathrm{g}^{-1}$.

\section{Histochemical analysis of starch granules}

Four repetitions of ten seeds per treatment were used. The sample fixation was done by using $5 \mathrm{~mL}$ formaldehyde, $5 \mathrm{~mL}$ acetic acid and $90 \mathrm{~mL}$ of ethanol 50\% during 48 hours in a freezer (BOUZON 1993). After fixation, samples were dehydrated using successive concentrations of ethanol $(30 \%, 40 \%, 50 \% 70 \%$, $90 \%$ and two times in ethanol 100\%), 30 minutes in each step (SCHMIDT 2009). The seeds were then preinfiltrated in a mixture historesin-ethanol (48 hours) and then infiltrated (48 hours) with Historesin (Leica Historesin, Heidelberg, Germany). Finally, sections of $5 \mu \mathrm{m}$ in length were stained with Lugol (JOHANSEN 1940) for starch visualization through a metachromatic reaction and investigated with an Epifluorescent (ZEISS) microscope equipped with Image Capture Software (Q-imaging Corporation, Austin, TX, USA).

\section{Data mining and statistics}

All data were summarized and subjected to statistical analysis and where differences were observed, Tukey Honestly Significant Differences (HSD) test was used $(p<0.05)$ as mean comparison test. All statistical analyses were performed in $R$ software (R CORE TEAM 2020) using scripts developed by our research group. 


\section{RESULTS}

\section{Physiological parameters}

The physiological parameters evaluated in this study are summarized in Table 1. According to the results, the rate of dormant seeds decreased significantly while increasing the concentration of gibberellic acid from zero (control treatment) to $500 \mathrm{mg} \mathrm{L}^{-1}(p<0.05$, Tukey test), meaning that gibberellic acid has an effect on dormancy-breaking of rice seeds.

Table 1. The effect of gibberellic acid concentrations on the germination evaluated as rate of dormant and non-dormant (\%) rice seeds.

\begin{tabular}{cccccc}
\hline $\begin{array}{c}\text { Gibberellic } \\
\text { acid } \\
\left(\mathrm{mg} \mathrm{L}^{-1}\right)\end{array}$ & $\begin{array}{c}\text { Dormant } \\
\text { seeds } \\
(\%)\end{array}$ & $\begin{array}{c}\text { Non-dormant } \\
\text { seeds } \\
(\%)\end{array}$ & $\begin{array}{c}\text { Normal } \\
\text { seedlings } \\
(\%)\end{array}$ & $\begin{array}{c}\text { Abnormal } \\
\text { seedlings } \\
(\%)\end{array}$ & $\begin{array}{c}\text { Inviable } \\
\text { seeds } \\
(\%)\end{array}$ \\
\hline 0 & $35 \mathrm{a}^{*}$ & $65 \mathrm{~b}$ & $32 \mathrm{a}^{*}$ & $22 \mathrm{~b}$ & $11 \mathrm{a}$ \\
500 & $4 \mathrm{~b}$ & $96 \mathrm{a}$ & $30 \mathrm{a}$ & $61 \mathrm{a}$ & $5 \mathrm{a}$ \\
1000 & $1 \mathrm{~b}$ & $99 \mathrm{a}$ & $29 \mathrm{a}$ & $62 \mathrm{a}$ & $8 \mathrm{a}$ \\
\hline CV (\%) & 22.43 & 3.4 & 20.31 & 8.79 & 53.68 \\
\hline
\end{tabular}

Similar letters in the column means non-significant statistical differences $(p<0.05$, Tukey test). CV $=$ Coefficient of variation

Contrarily, the rate of non-dormant seeds was observed to be higher in treatments where gibberellic acid was applied (Table 1). Despite the observed effect of gibberellic acid, it was also found that gibberellic acid has negative effect on seedling growth (Table 1). The rate of abnormal seedlings increased significantly in gibberellic acid treatments.

Gibberellic acid promoted a reduction in root length (Figure 1). Shoot and seedling length were significantly increased $(p<0.05)$ by gibberellic acid concentrations ( $500 \mathrm{mg} \mathrm{L}^{-1}$ and $1000 \mathrm{mg} \mathrm{L}^{-1}$, respectively). The optimum level of growth regulator to seedling length was $500 \mathrm{mg} \mathrm{L}^{-1}$. The results prompt us to postulate that at those levels of gibberellic acid used in this experiment, a growth regulator imbalance possibly caused accelerated rate o germination, promoting excessive development of shoots and inhibiting root growth.

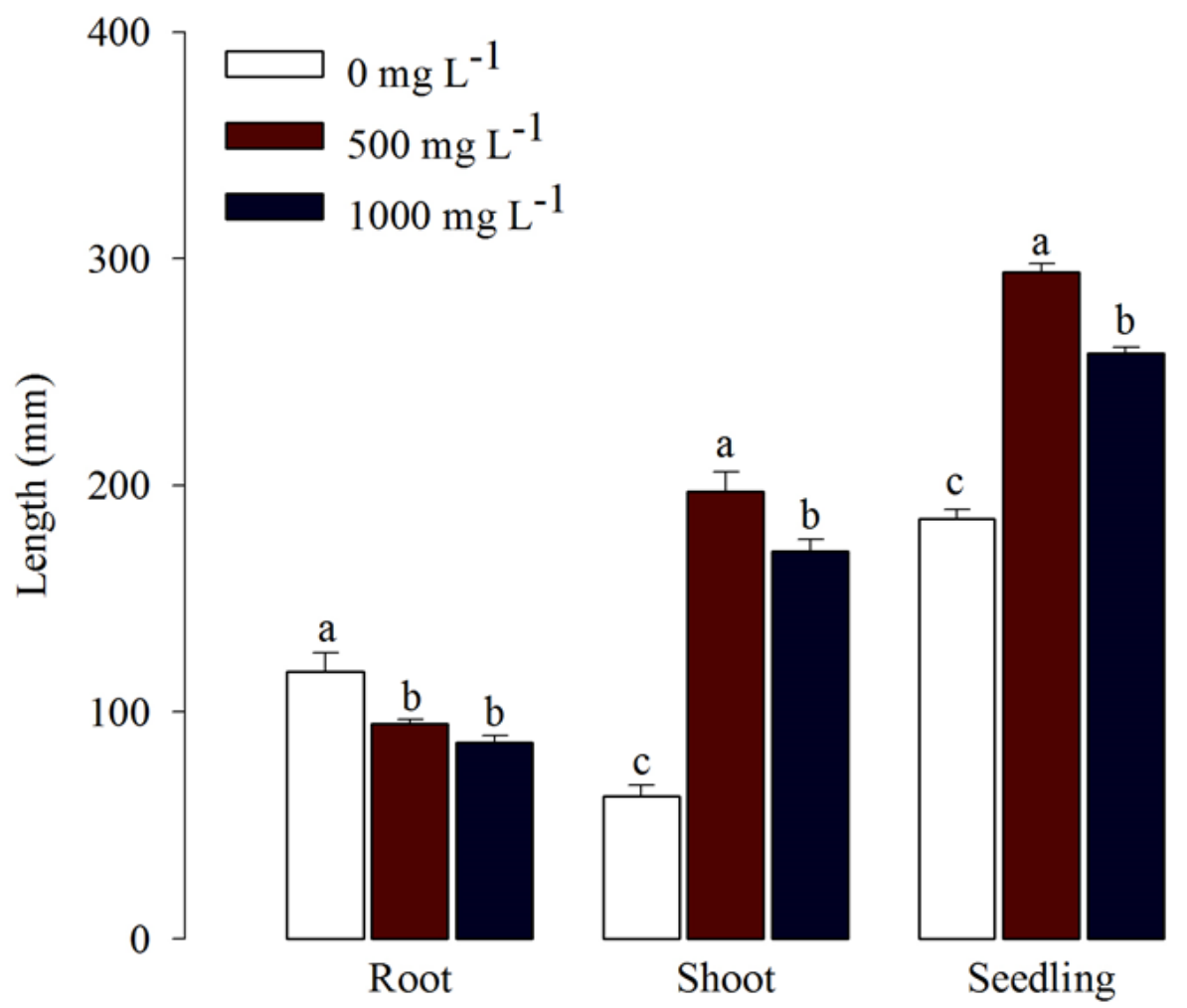

Figure 1. Root, shoot and seedling length $(\mathrm{mm})$ according to gibberellic acid concentrations $\left(0 \mathrm{mg} \mathrm{L}^{-1}, 500\right.$ $\mathrm{mg} \mathrm{L}^{-1}$ e $\left.1000 \mathrm{mg} \mathrm{L}^{-1}\right)$. Means followed by similar letters are statistically non-significant by Tukey $(p<0.05)$. 
Biochemical parameters: Histochemical analysis of starch granules of rice seeds after gibberellic acid treatments

Starch granules are clearly visible in its intact form in figure $2 \mathrm{~A}$ and where gibberellic acid was applied (Figure $2 \mathrm{~B}$ and $2 \mathrm{C}$ ). In Figure $2 \mathrm{~B}, 2 \mathrm{C}$ is starch degradation, possibly, the growth regulator stimulates amylases involved in starch degradation toward soluble sugar biosynthesis for growth and development of seedlings.
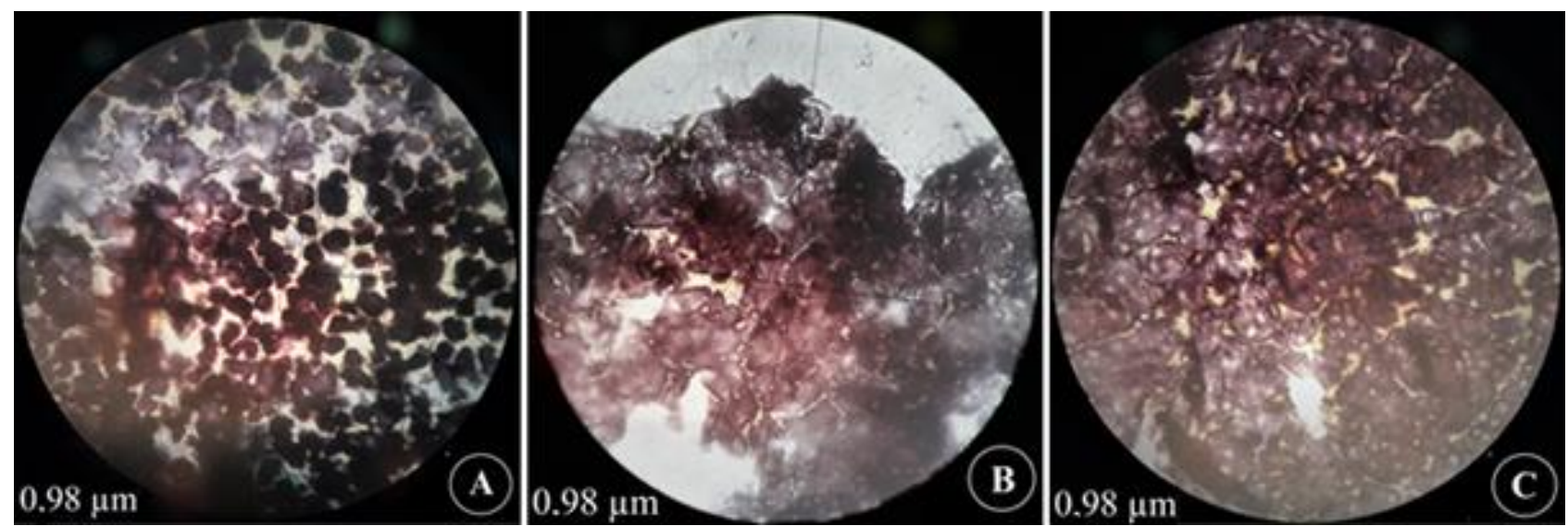

Figure 2. Light Microscopy of rice seeds endosperm after $46 \mathrm{~h}$ of imbibition in $0 \mathrm{mg} \mathrm{L}^{-1} \mathrm{GA}_{3}$ (water) (A), 500 $\mathrm{mg} \mathrm{L}^{-1}$ gibberellic acid (B) and $1000 \mathrm{mg} \mathrm{L}^{-1}$ gibberellic acid (C) showing starch granules.

TSS significantly increased with gibberellic acid application (Figure 3) after 46 hours of imbibition, which corroborates with our previous results (Figure $2 \mathrm{~B}$ and $2 \mathrm{C}$ ) in histochemical analysis. The presence of gibberellic acid promoted starch degradation while increasing soluble sugars for growth and development of seedlings.

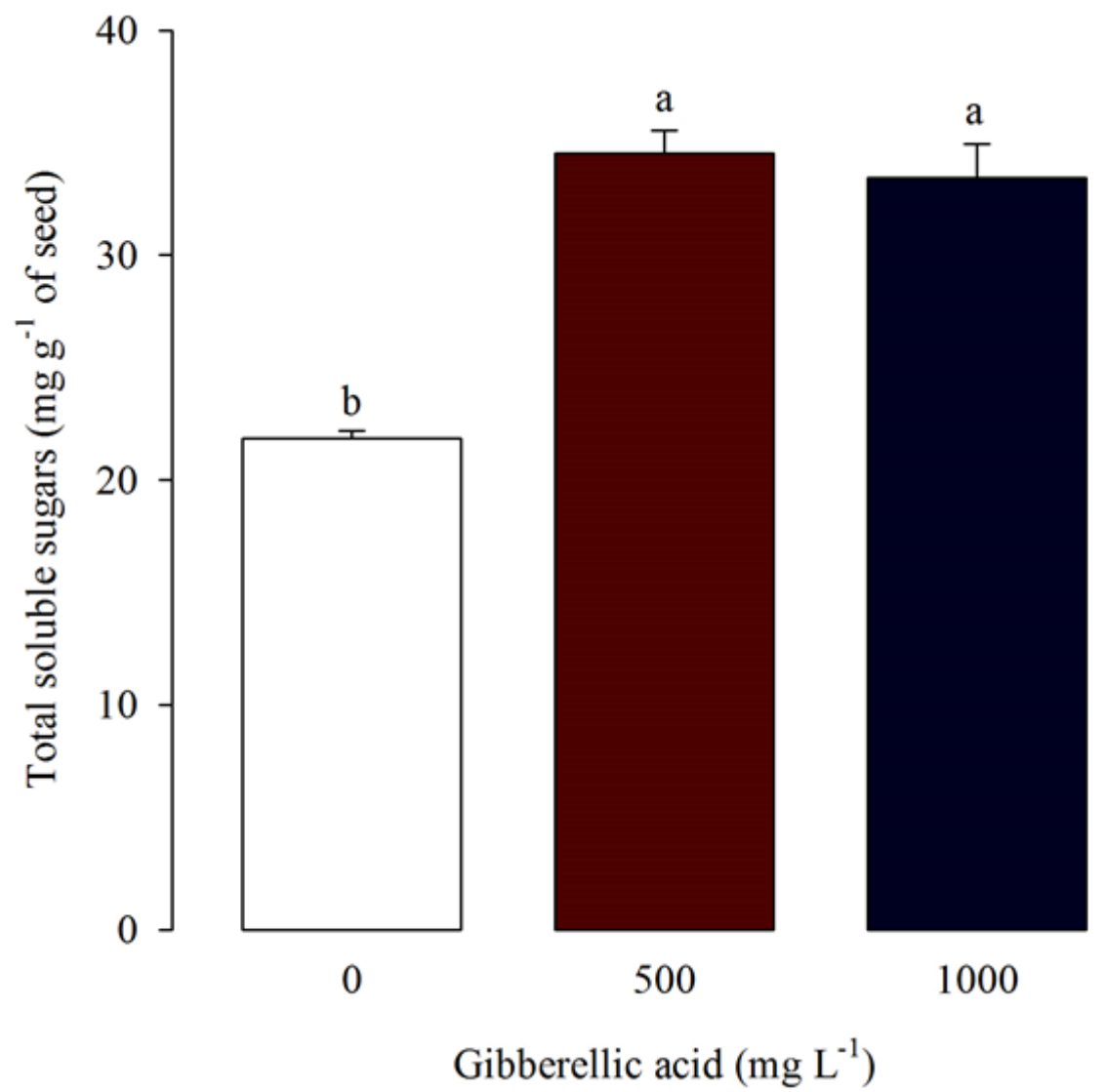

Figure 3. The effect of gibberellic acid concentrations on total soluble sugars of rice seeds. Similar letters mean statistically non-significant differences between the treatments $(p<0.05$, Tukey test). 


\section{DISCUSSION}

Gibberellic acid promoted the breaking of dormancy (Table 1). However, the rate of abnormal seedlings was significantly higher in gibberellic acid treatments (Table 1). The higher level of growth regulator probably accelerated the dormancy-breaking process and germination while reducing the needed time for membrane re-organization after hydration.

Similar results were reported by TONIN (2015) in wheat and sweet maize. Seeds treated with the highest concentration of gibberellic acid showed higher abnormal seedlings and inviable seeds. Research by ARAGÃO et al. (2003) observed that maize seeds treated with gibberellic acid higher than $100 \mathrm{mg} \mathrm{L}^{-1}$ showed a higher rate of abnormal seedlings, which prompted us to postulate that levels of gibberellic acid had a toxic effect on the treated seeds, compromising the seedling growth.

Furthermore, gibberellic acid affected the length of the seedlings, promoting shoot growth and inhibiting the seedling root. The levels of gibberellic acid used in this experiment caused a growth regulator imbalance, possibly accelerating the germination rate and promoting excessive development of shoots and inhibiting root growth.

KUMARI et al. (2017) also observed that gibberellic acid promoted seedling length in their research. For the shoot, the length increased while increasing the concentration of gibberellic acid. But, MIRANSARI \& SMITH (2014) reported that there can be interaction between growth regulators during germination process. Similar behavior was also observed by GROHS et al. (2012), who reported that gibberellic acid promotes excessive development of shoots than roots, and they concluded that due to higher rates of cell divisions which causes increases in node elongation (GRAEBE 1987). When there is excessive growth of shoots, the seedlings allocate more carbon to leaf and shoot nutrition than in roots which consequently causes a reduction in root growth (GROHS et al. 2012).

Previous results from histochemical analysis of starch granules showed that $\alpha$-amylases are present in dormant seeds at lower levels and during germination, the level is increased rapidly, which prompt us to conclude that soluble sugars from starch degradation via amylase activity are mobilized for embryo nutrition and seedling formation (VIEIRA et al. 2008).

Regarding the total soluble sugars (TSS) analyzed by UV-visible spectrophotometry, similar results were also reported by SUN et al. (2018). In their study, the authors reported a significant increase in soluble sugar after applying gibberellic acid in Zanthoxylum dissitum seeds for 24 hours. Contrarily, KHAN et al. (2011) observed lower levels of soluble sugars in wheat treated with gibberellic and kinetin.

As claimed previously, exogenous application of gibberellic acid promotes up-regulation of $\alpha$-amylases which have a role in starch hydrolysis to form soluble sugars (SUN et al. 2018). The aleuron layer is the responsible of $\alpha$-amylase production in response gibberellins (VIEIRA et al. 2010). In wheat seeds and other species of Poaceae family, aleuron layers are also responsible in reserve mobilization for germination process (TAIZ et al. 2017).

The antagonism of abscisic acid and gibberellic acid was also reported to affect seed dormancy via abscisic acid, inhibiting the biosynthesis of hydrolytic enzymes that are essentials for reserve catabolism and gibberellic acid inducing the biosynthesis of the same enzymes (TAIZ et al. 2017). Although, as in the seeds, abscisic acid is found in higher concentrations, the exogenous application of gibberellic acid caused a hormonal balance leading to starch degradation and its conversion to soluble sugars while promoting dormancy-breaking observed in our study. And it results can be used in future aiming to better understand the physiological and biochemical mechanisms during dormancy-breaking.

\section{CONCLUSION}

Gibberellic acid promotes dormancy-breaking in rice seeds via promoting starch degradation to soluble sugars, which are then utilized for the growth and development of seedlings.

Optimal concentrations are to be targeted in future studies due to the negative effect (high rate of abnormal seedlings) observed in our research.

Histochemical analysis combined with UV-visible spectroscopy were capable of finding tissue alterations which occur during gibberellic acid treatments in rice seeds.

\section{ACKNOWLEDGEMENTS}

Authors are thankful to CNPq-Brazil and CAPES-Brazil for providing fellowships for MSc and PhD degrees of first, third and fourth authors and grating research projects of Professor Cileide Coelho (project 2017TR653 PAP/UDESC/FAPESC). Virgílio Uarrota thanks CONICYT-FONDECYT project 3190055 and 
VICERRECTORIA DE INVESTIGACION Y ESTUDIOS AVANZADOS (VRIEA) of Pontificia Universidad Católica de Valparaíso for research facilities.

\section{REFERENCES}

ALENCAR NLM et al. 2012. Seed reserve composition and mobilization during germination and early seedling establishment of Cereus jamacaru D.C. ssp. jamacaru (Cactaceae). Annals of the Brazilian Academy of Sciences 84:823-832.

ALI AS \& ELOZEIRI AA. 2017. Metabolic Processes During Seed Germination. In: JIMENEZ-LOPEZ JC. Advances in Seed Biology. IntechOpen

ANDRADE GC et al. 2020. Modelling the vigour of maize seeds submitted to artificial accelerated ageing based on ATRFTIR data and chemometric tools (PCA, HCA and PLS-DA). Heliyon 6 e03477.

ARAGÃO CA et al. 2003. Atividade amilolítica e qualidade fisiológica de sementes armazenadas de milho super doce tratadas com ácido giberélico. Journal of Seed Science 25:43-48.

BALDI ME et al. 2012. Métodos alternativos para superação da dormência em sementes de arroz irrigado. Informativo Abrates 22: 16-19.

BEWLEY JD et al. 2013. Seeds: Physiology of development, germination and dormancy. 3.ed. New York: Springer. 407 p.

BOUZON ZL. 1993. Aspectos histoquímicos e ultra-estruturas da porção vegetativa e reprodutiva de estiquídios de Hypnea musciformis (Gigartinales- Rhodophyta). Dissertação (Mestrado em Biologia Celular e Molecular). Curitiba: UFPR.

BRASIL. 2009. Regras para análise de sementes. Brasília: Mapa/ACS. 398 p.

CLEGG KM. 1956. The application of the anthrone reagent to the estimation of starch in cereals. Journal of the Science of Food and Agriculture 7: 40-44.

COELHO CMM et al. 2010. Características morfo-agronômicas de cultivares crioulas de feijão comum em dois anos de cultivo. Semina Ciências Agrárias 31:1177-1186.

COX TS et al. 2010. Progress in breeding perennial grains. Crop \& Pasture Science 61:513-521.

GAO S \& CHU C. 2020. Gibberellin Metabolism and Signaling: Targets for Improving Agronomic Performance of Crops. Plant and Cell Physiology 61:1902-1911.

GRAEBE J. 1987. Gibberellins biosynthesis and control. Annual Review of Plant Physiology 38:425-457.

GROHS M et al. 2012. Desempenho de cultivares de arroz com uso de reguladores de crescimento em diferentes sistemas de cultivo. Pesquisa Agropecuária Brasileira 47:776-783.

JOHANSEN DA. 1940. Plant microtechnique.1rt edn. New York, McGraw-Hill Book Co. Ltd.

KHAN MB et al. 2011. Wheat seed enhancement by vitamin and hormonal priming. Pakistan Journal of Botany 43: $1495-$ 1499.

KUMARI N et at. 2017. Effect of halo priming and hormonal priming on seed germination and seedling vigour in maize (Zea mays L.) seeds. Journal of Pharmacognosy and Phytochemistry 6: 27-30.

LAVIS LD. 2011. Histochemistry: Live and in color. Journal of Histochemistry and Cytochemistry 59: 139-145.

LONG RL et al. 2015. The ecophysiology of seed persistence: a mechanistic view of the journey to germination or demise. Biological Reviews 90: 31-59.

MARCOS FILHO J. 2015. Fisiologia de sementes de plantas cultivadas. 2.ed. Londrina: Abrates.

MIRANSARI M \& SMITH D. 2014. Plant hormones and seed germination. Environmental And Experimental Botany 99: 110-121.

NAKAGAWA J. 1999. Testes de vigor baseados no desempenho de plântulas. In: KRZYZANOWSKI FC et al. (Eds.). Vigor de sementes: conceitos e testes. Londrina: Abrates. p.1-24.

NÉE G et al. 2017. The release of dormancy, a wake-up call for seeds to germinate. Current Opinion in Plant Biology 35 : 8-14.

R CORE TEAM. 2020. R: A language and environment for statistical computing. R Foundation for Statistical Computing.

SCHMIDT EC. 2009. Efeitos da radiação ultravioleta-B sobre a morfofisiologia de Kappaphycus alvarezii (Doty) Doty ex P. Silva (Gigartinales) variantes pigmentares verdes e vermelhas. Dissertação (Mestrado em Biologia Vegetal). Florianópolis: UFSC. 140p.

SHU K et al. 2016. Two Faces of One Seed: Hormonal Regulation of Dormancy and Germination. Molecular Plant 9:3445.

SUN $J$ et al. 2018. Exogenous gibberellin weakens lipid breakdown by increasing soluble sugars levels in early germination of Zanthoxylum seeds. Plant Science 280: 155-163.

TAIZ L et al. 2017. Fisiologia e desenvolvimento vegetal. 6.ed. Porto Alegre: Artmed.

TONIN I. 2015. Aplicação de ácido giberélico e superação de dormência em sementes de trigo. Dissertação (Mestrado em Ciência e Tecnologia de sementes). Pelotas: UFPel. 44p.

TOZZI HH \& TAKAKI M. 2011. Histochemical analysis of seed reserve mobilization in Passiflora edulis Sims fo. flavicarpa O. Deg. (yellow passion fruit) during germination. Brazilian Journal of Biology 71: 701-708.

UARROTA V et al. 2011. Histochemical Analysis and Protein Content of Maize Landraces (Zea mays L.). Journal of Agronomy 10:92-98.

VIEIRA AR et al. 2002. Action of gibberellic acid $\left(\mathrm{GA}_{3}\right)$ on dormancy and activity of a-amylase in rice seeds. Journal of 
Seed Science 24:43-48.

VIEIRA AR et al. 2008. Marcador isoenzimático de dormência em sementes de arroz. Journal of Seed Science 30: 8189.

VIEIRA EL et al. 2010. Manual de fisiologia vegetal. São Luís, EDUFMA.

YAO W \& SHEN Y. 2018. Effects of gibberellic acid and magnetically treated water on physiological characteristics of Tilia miqueliana seeds. Canadian Journal of Forest Research 48: 554-558.

ZHAO M et al. 2018. Mobilization and role of starch, protein, and fat reserves during seed germination of six wild grassland species. Frontiers in Plant Science 234:1-11. 